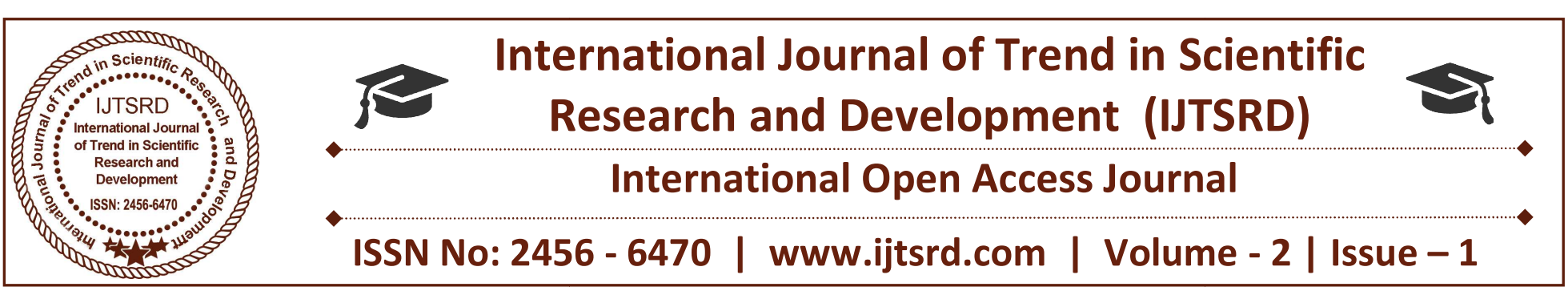

\title{
A Review on Rasadhyaya: It's Importance in Alchemy
}

\author{
Dr. Kavita \\ PG Scholar,Dept. of RSBK, Govt. \\ Ayurved College, Raipur, C.G., India \\ Dr. Gajendra Sahu \\ PG Scholar,Dept. of RSBK, Govt. \\ Ayurved College, Raipur, C.G., India
}

\author{
Dr. M. K. Dash \\ Lecturer, PG Dept. of RSBK, Govt. \\ Ayurved College, Raipur, C.G., India \\ Dr. S. M. Parhate \\ Professor \& H.O.D., PG Dept. of RSBK, Govt. \\ Ayurved College, Raipur, C.G., India
}

\author{
Dr. K. S. Karbhal \\ Reader, PG Dept. of RSBK, Govt. \\ Ayurved College, Raipur, C.G., India
}

\begin{abstract}
According to the development chronology, the use of Rasa Chikitsa Started from the $7^{\text {th }}$ century to the $10^{\text {th }}$ or $11^{\text {th }}$ century. With the use of Rasa-Rasayanadi, success in Dehavada \& Lohavada began to be successful and the attitude of Acharyas towards Rasa Chikitsa. In the tradition of Rasa Chikitsa, the Rasadhyaya written by Siddha Kankayala and his disciple comes. Rasadhyaya also comes in the classical treatise in high quality Rasagranthas. Its shaili (style), bhasha (language), nirmana prakara (method of drug formulations) \& mana nirupana (value representation) etc. keeps its own space. In this article, the special description of Rasadhyaya \& the contribution of Rasadhyaya in Rasa shastra have been described.
\end{abstract}

\section{INTRODUCTION}

In Rasashastra, the term rasa is indicative of Parada (Mercury). Since the Mercury does, the 'rasana' or 'aswadana' (engulf) of 'Abhrakadi rasa dravya' and 'Swarnadi dhatu' it is called 'Rasa'. Since its judicious therapeutic use slows down aging process (jara), heals many diseases (ruja) and delays death (mrityu), it is called 'Rasa'.' (1) The 'Rasaushadhis' are known for smaller dosage. They do not cause any nauseating sensation during consumption. These medicines provide quick results and they are useful in majority of difficult to cure disease conditions. These medicines are also good appetizers and digestives. ${ }^{(2)}$ Rasadhyaya is an authoritative text on Rasashastra and contains all the details of various procedures involved in drug purification and preparation. Rasadhyaya is an ancient and authentic book in its time. It has more importance in the contemporary Rasagrantha (Rasa text) Hence its Rasadhyaya name is meaningful.

\section{PREDICTION OF PERIOD}

There is no any specific time period is given in the book. Rasadhyaya Author Kankalaya seems to be ancient, because their preaching period is not known. It can be said that it was contemporary of the Yawan rajya. Because he has used Yawan shashan kalik maap (measure) Valla, Gadyad, Man etc.in his book.

\section{AUTHOR DETAILS \& COMMENTARIES}

In the tradition of Rasa Chikitsa, the Rasadhyaya written by Siddha Kankayala and his disciple comes. Rasadhyaya nibandhan has been done by Champaka, as it appears from the last stanza of the book. Siddha Kankalayan preached his follower whose name is not mentioned, he gave this text a form \& Champak essayed it with detail. Champak himself introduced as the name of Champak, son of Adi in Yadav Vanshiya tradition \& the history of the treatise has indicated the $14^{\text {th }}$ Century. The name of his mentor was Mahendra prabha. The commentary of Rasadhyaya is done by 
Merutund Jain in 1386 A.D.

\section{MATERIALS \& METHODS-}

After going through the subject matter of Rasadhyaya, it is found that the whole text is completed in 21 specific chapters known as Adhikar. The whole book is mainly based on 18 specialized processing techniques of Mercury i.e.Samskar and on affecting other metals by Parada (Mercury). However it is not only a text of Alchemy but also used as medical treatise.

\section{$1^{\text {st }}$ Adhikar-Shrinkhla rasa, Parada samskar}

- This Adhikar (chapter) starts with Namaskaratmak Mangal.

- Parada sapt kanchuk dosha (mritika maya, pashan maya, jaljata maya, nagaj, vangaj, shyama, kalika), Parada pancha dosha (mala, vahni, visha, darp, unmatta) \& Dosha mukt Parada are described.

- After Eighteen samskar Parada gets Dehasiddhi \& Lohasiddhi.

- This chapter is called Shrinkhla Rasa due to the description of Parada Samskar in a series of ways. The samskar are Patsaran, mardana, shodhan, murchanothapana, rasapatana, rasa utthana, swedana, niyamana, nirodhan, mukhkari, jarana, vedhkrut, sarana, marana, pratisarana, kramana, vedhan \& uddhatan.

- Superiority of Parada over other Rasayana drugs. Abhraka shodhana, Jirna abhraka jarana vidhi, Jirna abhraka parada jarana vidhi, Dhanyabhraka lakshan, Abhra-pisti nirmana vidhi also described in this adhikar.

- Acharya has also described the opinions of other Acharya's with their views. ${ }^{(3)}$

$2^{\text {nd }}$ Adhikar - Hemaraji, Ghoshraji, Makshikraji, Nagaraji detail

- In $2^{\text {nd }}$ Adhikar Rajiswarup nirupana is mentioned for the Jarana of Parada (Mercury).

- In this chapter there is a representation of nature of Hemaraji. For Jarana, add 1/64 part of Hemaraji to 8 times of Parada (Mercury).

- Hemaraji, Nagaraji, Prakashraji, Kamsyaraji, Makshikraji are described.

- Nagaraji is common Raji, Makshikraji is medium,
Kamsyaraji is good \& the Prkashraji is the best. ${ }^{(4)}$

$3^{\text {rd }}$ Adhikar-Khapar Satvapatana

- In this Adhikaar Satvapatana of Khapar is described.

- For the Khapar satvapatan, Tumbanali yantra is described.

- Also Kacchapakar musa, Vartulakar musa and Bhudhar yantra are described for Kharpar satvapatana. ${ }^{(5)}$

\section{$4^{\text {th }}$ Adhikar-Manahshila Satvapatana}

- Manahshila satvapatana is described in this chapter.

- For the Manahshila satvapatan Kupipakva (kanch kupi) is described. ${ }^{(6)}$

\section{$5^{\text {th }}$ Adhikar - Shadloha marana vidhi}

- In this chapter 6 types of Loha marana is described.

- For Naga marana Manahshila is used, for Vang marana Hartal is used, for Loha marana Hingula is used, for Tamra marana shuddh gandhak (pure sulpher) is used, For Rajat marana Tilmakshik is used and for the Swarna marana Naga is used.

- Marana processes for all metals are same. ${ }^{(7)}$

$6^{\text {th }}$ Adhikar - Tridha Shadloha drutikarana vidhi

- 3 types of Shadloha drutikarana vidhi is described in this Adhikar.

- Shadloha druti are Hemadruti, Raupyadruti, Tamradruti, Lohadruti, Nagadruti and Vangadruti.

- Sphatika, Tankan kshar, Devdali panchang and gomutra are described for Shadloha druti. ${ }^{(8)}$

$7^{\text {th }}$ Adhikar - Tridha Annapathkaran vidhi

- Annapathkaran vidhi for the Heerak jarana.

- 3 types of Heerak Annapathkaran (jarana) are described by the use of Kukkut puta. ${ }^{(9)}$

$8^{\text {th }}$ Adhikar-Panchadha Heerakbhasmikaran vidhi

- This chapter described the Heerak (diamond) pariksha and it has been said that Heerak does not burn by fire, does not break on falling and does not 
drown in water, so it is difficult to test.

- So for the test of Heerak, take the Heerak in the hand and rub it on. In which there is no single line and whose shine does not decrease, it is called natural Heerak.

- Five types of Heerak bhasma are described. ${ }^{(10)}$

$9^{\text {th }}$ Adhikar - Dwidha Gandhak shodhana vidhi

- Sthali patra is described for the two types of Gandhak shodhan vidhi.

- In the Rasa karma, the use of shuddh Gandhak (pure sulpher) in both these forms is described. ${ }^{(11)}$

\section{$10^{\text {th }}$ Adhikar - Dwidha Gandhakpithi nirmana vidhi}

- Two types of Gandhakpithi is described in this chapter.

- In first method- in clean Tamra patra (copper vessel) keep pure sulpher and pure Mercury and mantle well with finger. with this method, Parad and Gandhak pithi has been prepared.

- In second method - Make Kajjali from 1 part of pure Mercury and equal part of pure Gandhak. Make pithi by adding Shrikhand rasa/ Hemavalli rasa in Kajjali. After this Kajjali has been kept in saravsamput and placed in the Kukkut puta.

- In this chapter, Swarna (gold) nirman vidhi has been mentioned. Melt 384 grams of Silver and mix 6 grams of Sulpher in it, from this method Panchdash (fifteen) coloured Swarna (gold) are produced. This Gandhak pithi is helpful in the work of gold producers (swarna nirman karta). ${ }^{(12)}$

\section{$11^{\text {th }}$ Adhikar-Gandhak Taila nirmana vidhi}

- Gandhak Taila nirmana (formation of sulpher oil) vidhi is described in this chapter.

- By the use of $60 \mathrm{kgs}$ Pashan churna (chuna), 40 kgs Gandhak and $40 \mathrm{kgs}$. Sajji kshara water, the method of oil production has been described. ${ }^{(13)}$

\section{$12^{\text {th }}$ Adhikar - Gandhak Taila dwara Tridha} Hemakarma vidhi

- In this chapter three types of Hema nirmana vidhi is described by the use of Gandhak taila. ${ }^{(14)}$ $13^{\text {th }} \quad$ Adhikar - Gandhak Taila dwara Sahastrabedharasa vidhi

- In this chapter Hema nirmana vidhi (with sahastravedhak khot) is described by the use of Gandhak taila and Hemaraji jeerna Parada.

- For the making of different Hema different metals (Tamra, Naga, Vanga etc) are used. ${ }^{(15)}$

\section{$14^{\text {th }}$ Adhikar-Gandhak Druti-Pithi nirmana vidhi}

- In this chapter Ghandhak Druti -Pithi nirmana vidhi is described by the use of Sajji kshara water, Gandhak and Abhraka (in Kumbh kupi). ${ }^{(16)}$

\section{$15^{\text {th }}$ Adhikar - Gandhak Druti-Pithi karm vidhi}

- In this chapter of Rasadhyaya, the Karma (function) of Gandhak (Sulpher) has been described.

- Gandhak Druti-Pisti is used for Swarna nirmana, for Parada bandha and pota nirman and also used for best Swarna nirmana. ${ }^{(17)}$

\section{$16^{\text {th }}$ Adhikar-Talaka shodhana vidhi}

- In this chapter Godanti Hartal purification method is described. Five types of drugs are essential for shodhana (purification) of Godanti Harital- 1) Lime water, 2) Kusmand juice, 3) Milk, 4) water of Vadvai and 5) Kanji (with salt).

- Disorders due to the consumption of unclean Godanti Hartal have been described. ${ }^{(18)}$

\section{$17^{\text {th }}$ Adhikar-Tala karm nirupan}

- In this chapter function of pure Hartal has been described.

- The person who consumes pure Hartal per day in quantity of 1 Ratti, will became free from 18 types of Kustas within 6 months. His new teeth comes out and hair becomes black. ${ }^{(19)}$

\section{$18^{\text {th }}$ Adhikar - Tridha Abhraka Drutikaran vidhi}

- In this chapter described the three types of Abhraka Druti nirmana vidhi. ${ }^{(20)}$

\section{$19^{\text {th }}$ Adhikar-Abhraka Drutikaran karya}

- In this chapter three types of Dhanyabhraka Druti Karma has been described.

- The person who consumes $120 \mathrm{mg}$. of Abhraka 
Druti, has becomes Tejasvi (stunning), Nischal (clean) and Akshay (renewable) within 6 months. Deha siddhi and Loha siddhi are achived through its intake. ${ }^{(21)}$

\section{$20^{\text {th }}$ Adhikar - Hemavajra Bhasma, Bhunaag-satva- nispanna karma}

- In this chapter Hemavajra bhasma and Bhunaagsatva nirupana karma has been described. - It promotes strengthening and beauty of the body.

\section{$21^{\text {th }}$ Adhikar-Kilavaalvadini Gutika nirmana vidhi}

- In the last Adhikar (chapter) of the Rasadhyaya, Acharya described the Gutikanjana and Balvadini gutika and its preparation methods. ${ }^{(23)}$

\section{DISCUSSION}

Many words and preparation processes in this text differ from other texts. There are some words that are not known by dictionaries and other texts, like Karpar, Kodiyaka, Siddhachakra, Valla, Gadyaan, Mana, Dugdhpali, Leehalaka, Kumbak etc. which do not have clear knowledge from the dictionary. Acharya's unique contribution is seen in this text. In this text, the methods of Parada Samskar are different from other contemporary texts. In the order of the Parada Samskar, he first described the Patsarana, which is their fundamental contribution. In this text Acharya explained the process of Heerak (diamond) testing and the formation of Gandhak oil. Gold production has been described by Gandhak oil and Gandhak-DrutiPisti. Description of different types of Druti in the maximum chapters, are the speciality of the text. In this text Acharya quoted that Dehavada and Lohavada will be achived by the consumption of Parada formulations, Khot formulations and Gutika formulations. Acharya has highly praised the treatment of Rasaaushadhi very effectively. In Rasadhyaya the Author has included different types of Druti, Pisti and Rasa aushadhies by his own experience. There is no any dought that Rasadhyaya is one of the best texts of its time. In modern era it is also very useful in the preparation of various pharmaceutical formulations.

\section{CONCLUSION}

In this text very systematic description of Parada Samskar (Astadasha) has been described not only for the metallic transformation but also for the metabolic transformation by which body will become strong and healthy. The features of Rasa therapy is that it works quickly and gives health immedietly. Rasadhyaya is known for its virtue of practical usefulness. It gives contribution to the development of Rasashastra through various methods of preparations of Rasa-yogas. Chapters and its contents are well arranged. Rasadhyaya is an important text on Ancient Indian Alchemy and therapeutics. The subject matter of the text is focused on performance and alternative methods of experimentation.

\section{REFERENCES}

1. Dattatrey Anant Kulkarni, Rasa ratna samucchaya, Meharchand Lakshman publication, New Delhi, Reprint 2010, 1/77, pp:9

2. Pt. Ramprasad, Rasendra sara samgrah, Khemraj ShriKrishnadas Publication, Mumbai, edition 2009,1/4, pp:2

3. Dr. Indradeva Tripathi, Rasadhyaya, Chaukhambha Sanskrit Sansthan, Varanasi, second edition-1982, pp: $1-49$

4. Dr. Indradeva Tripathi, Rasadhyaya, Chaukhambha Sanskrit Sansthan, Varanasi, second edition-1982, pp: $49-53$

5. Dr. Indradeva Tripathi, Rasadhyaya, Chaukhambha Sanskrit Sansthan, Varanasi, second edition-1982, pp: $53-54$

6. Dr. Indradeva Tripathi, Rasadhyaya, Chaukhambha Sanskrit Sansthan, Varanasi, second edition-1982, pp: 54-55

7. Dr. Indradeva Tripathi, Rasadhyaya, Chaukhambha Sanskrit Sansthan, Varanasi, second edition-1982, pp: 58-59

8. Dr. Indradeva Tripathi, Rasadhyaya, Chaukhambha Sanskrit Sansthan, Varanasi, second edition-1982, pp: $55-58$

9. Dr. Indradeva Tripathi, Rasadhyaya, Chaukhambha Sanskrit Sansthan, Varanasi, second edition-1982, pp: 59-63

10. Dr. Indradeva Tripathi, Rasadhyaya, Chaukhambha 
Sanskrit Sansthan, Varanasi, second edition-1982, pp: 63-68

11. Dr. Indradeva Tripathi, Rasadhyaya, Chaukhambha Sanskrit Sansthan, Varanasi, second edition-1982, pp: $68-69$

12. Dr. Indradeva Tripathi, Rasadhyaya, Chaukhambha Sanskrit Sansthan, Varanasi, second edition-1982, pp: $69-70$

13. Dr. Indradeva Tripathi, Rasadhyaya, Chaukhambha Sanskrit Sansthan, Varanasi, second edition-1982, pp: 71-72

14. Dr. Indradeva Tripathi, Rasadhyaya, Chaukhambha Sanskrit Sansthan, Varanasi, second edition-1982, pp: $72-75$

15. Dr. Indradeva Tripathi, Rasadhyaya, Chaukhambha Sanskrit Sansthan, Varanasi, second edition-1982, pp: $75-76$

16. Dr. Indradeva Tripathi, Rasadhyaya, Chaukhambha Sanskrit Sansthan, Varanasi, second edition-1982, pp: $76-77$

17. Dr. Indradeva Tripathi, Rasadhyaya, Chaukhambha Sanskrit Sansthan, Varanasi, second edition-1982, pp: 77-79

18. Dr. Indradeva Tripathi, Rasadhyaya, Chaukhambha Sanskrit Sansthan, Varanasi, second edition-1982, pp: 79-81

19. Dr. Indradeva Tripathi, Rasadhyaya, Chaukhambha Sanskrit Sansthan, Varanasi, second edition-1982, pp: $81-84$

20. Dr. Indradeva Tripathi, Rasadhyaya, Chaukhambha Sanskrit Sansthan, Varanasi, second edition-1982, pp: $85-88$

21. Dr. Indradeva Tripathi, Rasadhyaya, Chaukhambha Sanskrit Sansthan, Varanasi, second edition-1982, pp: 89-91

22. Dr. Indradeva Tripathi, Rasadhyaya, Chaukhambha Sanskrit Sansthan, Varanasi, second edition-1982, pp: 91-94

23. Dr. Indradeva Tripathi, Rasadhyaya, Chaukhambha Sanskrit Sansthan, Varanasi, second edition-1982, pp: 94-100 